\title{
Downregulation of epithelial MHC II expression in chronic rhinosinusitis with polyps
}

\author{
Julia Arebro ${ }^{1 *}$, Lotta Tengroth ${ }^{1}$, Susanna Kumlien Georén ${ }^{1}$, Ola Winqvist ${ }^{2}$, Lars-Olaf Cardell ${ }^{1}$ \\ From 9th Symposium of Experimental Rhinology and Immunology of the Nose (SERIN 2013) \\ Leuven, Belgium. 21-23 March 2013
}

\section{Background}

Inflammation in the nasal mucosa has been shown to correlate with the development of CRSwNP (chronic rhinosinusitis with nasal polyps). The mechanism behind this is not fully understood but changes in the activity of the immune system might contribute to the growth of polyps. The present study focuses on the potential role of MHC II (major histocompatibility complex class II). These cell surface proteins are of critical importance for the function of cells in the immune system and potentially in nasal polyp development.

\section{Methods}

Biopsies from polyps were obtained from patients with CRSwNP (with and without local steroid treatment during at least six consecutive weeks) as well as from the mucosa (concha inferior) of healthy control subjects. The obtained specimens were homogenized and subsequently analysed with flow cytometry.

\section{Results}

Preliminary data indicates a downregulation of MHC II expression in polyp epithelial cells from patients with CRSwNP compared to healthy patients (healthy controls: $60,2 \pm 7,8$; polyps $31,1 \pm 7,4 ; \mathrm{p}<0,05$ ). This reduction seems to be independent of the steroid treatment. In contrast, the level MHC II+/CD86+ on epithelial cells was downregulated in patients receiving steroid treatment but not in those without treatment. The mechanisms involved are presently investigated in mice.

\section{Conclusion}

Expression of MHC II and its co-receptor CD86 can be seen on epithelial cells in the mucosa of healthy controls

'Karolinska University Hospital, Division of ENT Diseases, CLINTEC, Stockholm, Sweden

Full list of author information is available at the end of the article as well as within the polyps of CRSwNP patients. This suggests a role for epithelial cells in the antigen-presenting procedure. Change of the MHC II expression, altering the inflammatory activity in response to invading microorganisms, might contribute to the development of polyps.

\section{Author details}

${ }^{1}$ Karolinska University Hospital, Division of ENT Diseases, CLINTEC, Stockholm, Sweden. ${ }^{2}$ Karolinska University Hospital, Department of Medicine, Unit of Clinical Allergy R, Stockholm, Sweden.

Published: 16 July 2013

\section{doi:10.1186/2045-7022-3-S2-O9}

Cite this article as: Arebro et al:: Downregulation of epithelial MHC II expression in chronic rhinosinusitis with polyps. Clinical and Translational Allergy 2013 3(Suppl 2):09.
Submit your next manuscript to BioMed Central and take full advantage of:

- Convenient online submission

- Thorough peer review

- No space constraints or color figure charges

- Immediate publication on acceptance

- Inclusion in PubMed, CAS, Scopus and Google Scholar

- Research which is freely available for redistribution
C Biomed Central

\section{Biomed Central}

